\title{
Die gelykenisse van Jesus: Klassifikasie en prediking*
}

\author{
$A G$ van Aarde
}

\section{Abstract}

The parables of Jesus: Classification and preaching

The article's intention is to evaluate with a pragmatic aim in mind, viz preaching, the traditional classification of Jesus' parables under the headings similitude, parable-proper, example-story and allegory. The basic thesis is that the emphasis should be on metaphoricity, narrativity and reference rather than the above-mentioned formgeschichtliche categories. The story of the Good Samaritan in Luke 10: 25-37 serves as a case study.

\section{INLEIDING}

Tekste kan nie geïnterpreteer word as vrae nie daaraan gestel word nie. Vrae kan egter irrelevant blyk te wees en selfs illegitiem. Wat bepaal die relevansie van die vrae wat die interpreteerder van Jesus se gelykenisse in die Nuwe Testament mag stel? Die pragmatiese doelwit van die interpretasie is myns insiens die antwoord op hierdie vraag. Dit kom daarop neer dat dit nodig is om nie net duidelikheid te kry oor die motief wat grondliggend aan die oorspronklike gebruik van die gelykenisse sou gewees het nie, maar ook oor die praktiese bruikbaarheid van die resultate wat bepaalde vraagstellings lewer. Die geldigheid van die vrae word weer veral deur die literêre aard van die gelykenis bepaal. Dié aard kan op sowel die evolusionêre, historiese ontstaan as die sinkroniese, koherente poëtiek van die gelykenis betrekking hê. Wat in die interpretasie op die voorgrond sal tree, die ontstaansgeskiedenis of die poëtiek van 'n gelykenis, behoort deur die interpreteerder na aanleiding van die pragmatiese doelwit uitgemaak te word. Indien dit met die oog op byvoorbeeld die prediking geskied, moet die kommunikatiewe moontlikhede en die kommunikatiewe voorwaardes van die bepaalde keuse egter deeglik in ag geneem word.

Kommunikasie word in 'n groot mate deur kommunikasie-strategieë bewerkstellig. Die literêre vorm is ongetwyfeld een van die belang-

"Referaat gelewer voor die Hervormde Teologiese Vereniging op 26 Junie 1985. 
rikste strategieë in die kommunikasie van literatuur. Hierdie aangeleentheid raak die ou probleem van die verhouding tussen vorm en inhoud. Reeds by Hermann Gunkel (Ou Testament) en Johan G Herder (Nuwe Testament), teen die wisseling van die negentiende en twintigste eeu, was die insig oor die samehang tussen vorm en inhoud 'n faktor by die interpretasie van Bybelse tekste. Dit is egter eers in die jongste tyd dat die hermeneutiese implikasies van hierdie samehang raakgesien en in die eksegese met 'n pragmatiese doelwit benut word. Die rede hiervoor is dat die identifisering van die 'generiese' literêre konvensie help om die teks se kommunikatiewe gerigtheid (intensie), en dit wat die interpreteerder enersyds van die teks moet verwag en andersyds aan die teks mag vra, te snap. Hirsch (1967: 76) formuleer dit soos volg: 'All understanding of verbal meaning is necessarily genrebound.' Daarom is die besef dat die vasstelling van die intensie van ' $n$ teks meer is as bloot die onderskeid tussen vorm en inhoud, al hoe meer by Bybelondersoekers merkbaar (kyk Van Aarde 1982: 7-9). "That genre must stand at least partly to indicate something beyond form, I take to be self-evident. Meaning, a common way to designate this additional factor, is genre-bound ... since generic expression must rank among the most important signal-systems used by the author' (Doty 1972: 430).

Nuwetestamentici onderskei, wat die gelykenisse van Jesus betref, reeds sedert Adolf Jülicher (1910) [1888; 1889], op die voetspoor van Aristoteles, tussen vergelyking en metafoor en na aanleiding hiervan tussen enersyds vergelyking, gelykenis (= parabel) en voorbeeldvertelling en andersyds metafoor en allegorie. Hierdie klassieke klassifikasie het sedertdien sterk onder die spervuur gekom. Van die kant van die nuwe-hermeneutici (bv Ernst Fuchs) is die onderskeid wat tussen vergelyking en metafoor getref word, veral op grond van die 'Sprachkraft der Existenz' (Fuchs 1958: 211-214; vgl ook Kingsbury 1972: 102) bevraagteken en selfs ontken (kyk later). In die kring van die Formgeschichtler (bv Rudolf Bultmann 1967: 188 en Martin Dibelius 1971: 249) is Jülicher se onderskeidinge egter grotendeels gehandhaaf. Maar hoe meer die positivisme van hulle literatuur- en geskiedenisbeskouing aan die kaak gestel is, hoe meer word die tradisionele klassifikasie as irrelevant beskou.

Sedert die formgeschichtliche periode word daar in die gelykenisnavorsing, met betrekking tot klassifikasie, nie soseer oor Aristoteles of in Aristoteliese terme gedebatteer nie (kyk Bultmann 1967: 214), maar gaan dit oor die verband tussen die identifisering van die vorm en die 
funksionele, kommunikatiewe gerigtheid daarvan. Bultmann, byvoorbeeld, se eie bydrae ten opsigte van gelykenisinterpretasie, naas sy interesse in die gelykenisse se tradisiegeskiedenis, is die beskrywing van die tegniek van die vertel van gelykenisse ('die Technik der Gleichniserzählung') (Bultmann 1967: 203). Hoewel hy dit nie eksplisiet vermeld nie, is die veronderstelling duidelik, naamlik dat die verteltegniek kommunikasie-strategieë is wat die motief van die gebruik van Jesus se gelykenisse in die vroeë kerk help verklaar. Bultmann (1967: 203-208) bespreek die kompaktheid van die gelykenisse as vertellinge met betrekking tot karakterisering, woordekonomie, ensovoorts, die enkelvoudige dominante perspektief daarin, die ryk voorkoms van direkte rede en monoloë, herhaling, die antisipasie van die hoorder/leser se beslissing ten opsigte van die punt wat die gelykenis wil makk en ten slotte die 'Gesetz de Achtergewichts' (Engels = law-of-end stress). Laasgenoemde stilistiese kenmerk kom daarop neer dat die belangrikste inligting laaste genoem word. Dit is 'n aspek wat algemeen in triviale, folkoristiese literatuur voorkom.

Die identifisering van die verskillende vorme waarin gelykenisse uiteenval, en van die onderskeie stilistiese kenmerke daarvan, behoort dus nie meer net 'n kwessie van klassifisering en benaming as ' $n$ doelwit op sigself te wees nie. Die eksegeet moet die hermeneutiese implikasies van die klassifisering in ag neem. En indien die eksegeet ook ' $n$ homileet is, moet hy homself afvra watter implikasies die klassifisering vir die prediking het. Die bedoeling van die onderhawige artikel is om die tradisionele klassifikasie van die gelykenisse in die Nuwe Testament te bespreek en aan 'n pragmatiese doelwit, soos die prediking, te toets. Die gevolgtrekking is dat ' $n$ beklemtoning van metaforisiteit in samehang met narratiwiteit en referensie vir die prediking meer funksioneel sal wees. Die gelykenis van die barmhartige Samaritaan (Luk 10: 25-37) word as voorbeeld gebruik.

\section{JÜLICHER SE ONDERSKEID TUSSEN VERGELYKING EN METAFOOR}

Tradisioneel is die onderskeid wat Jülicher (1910: 52) tussen 'n vergelyking en 'n metafoor getref het, die basis van die verdere onderskeidinge en eventuele klassifisering van die gelykenisse in die Nuwe Testament. Die kem van die onderskeid is dat ' $n$ vergelyking as ' $n$ eigentliche rede op 'n Ahnlichkeitsrelation sou berus, terwyl 'n metafoor te doen het met die literêre verskynsel dat twee vergelykbare objekte 
('n 'subjek' is soos ' $n$ 'predikaat' - oftewel 'Achilles is soos ' $n$ leeu') in 'n uneigentliche diskoers geartikuleer is (vgl Kissinger 1979: 72).

Metaforisiteit word hiervolgens gesien as bloot ornamentele diksie. Met dié uitdrukking word bedoel dat die 'subjek' nie nuwe informasie oor die 'predikaat' verskaf nie (vgl Weder 1978: 76-77). 'Ornamentele diksie' wil dus sê dat 'n metafoor ' $n$ Mimesis des Seienden (= ' $n$ afbeelding van die werklikheid) is. Só gesien, is die metafoor, volgens die begripsmatige taal van die Aristoteliese logika, herleibaar tot die bedoelde predikaat in die werklike wêreld (vgl Sellin 1982: 381). Die frase, byvoorbeeld, 'die leeu het aangestorm', se werklike bedoeling kan met ander woorde agtergekom word deur die 'subjek' leeu met Achilles te vervang. Om saam te vat, die metafoor 'Achilles is (soos) 'n leeu' (1) verwys indirek (dit wil sê op 'n uneigentliche wyse) na die bedoelde werklikheid en (2) vereis derhalwe transformasie (oftewel interpretasie), maar (3) verskaf geen nuwe informasie ten opsigte van die 'predikaat' (leeu) nie.

Hierteenoor het die vergelyking geen interpretasie nodig nie. Die doel daarvan is om te leer, dit wil sê dit is didakties van aard. In die terme van die genoemde voorbeeld sal die frase, 'Achilles storm aan soos ' $n$ leeu', 'n vergelyking wees. Wat tussen die vergelyking en die metafoor gemeenskaplik is, is dat beide op analogie berus. Daarmee word bedoel dat beide ' $n$ 'subjek' na analogie van ' $n$ 'predikaat' benoem. Jülicher verduidelik die verskil tussen 'n vergelyking en 'n metafoor deur die analogiese prinsiep by eersgenoemde in terme van iets soortgelyk ('Anschaulichkeit') te sien en by laasgenoemde in terme van vervanging ('Substitution') (kyk Sellin 1982: 368). Die verwysing tussen die 'subjek' en die 'predikaat' vind by 'n vergelyking dus direk plaas (die sg Ähnlichkeitsrelation-prinsiep). Die hoorder/leser weet onmiddellik hoe die een ding gebruik word om die ander te demonstreer. Hy/sy kan derhalwe vanuit die Ähnlichkeitsrelation 'n algemene waarheidsbeginsel wat didakties van aard is, aflei.

Jülicher het gemeen dat die gelykenisse van Jesus in die Sinoptiese Evangelies vergelykings is en nie metafore nie. Hy het as kind van die voor-formgeschichtliche 'Leben Jesu Forschung' (kyk Wrege 1978: 11) die gelykenisse van Jesus 'gesien as die verwoording van algemene (morele) waarhede' (Pelser 1985: 459). Hiermee het hy weggedoen met die allegoriserende en onthistoriserende tendens in die eksegese en prediking van die gelykenisse, maar aan die ander kant die weg ongelukkig gebaan tot moraliserende en selfs romantiserende prediking. 
Jesus is in sulke tipe prediking op 'n romanties-idealiserende wyse as die eksemplaar van morele deugde voorgehou.

Later in die artikel word daar ingegaan op die onhoudbaarheid om tussen ' $n$ 'vergelyking' en ' $n$ 'metafoor' in bogenoemde terme te onderskei. Hierdie kritiek gaan uiteraard 'n wesenlike uitwerking op die eksegese en prediking van Jesus se gelykenisse hê. Dit raak immers op 'n ingrypende wyse die tradisionele klassifisering in onderskeidelik vergelykings (in enger sin), parabels, voorbeeldvertellinge en allegorieë. (Laasgenoemde kom volgens sommige gelykenisnavorsers wel spaarsaam in die Nuwe Testament voor.)

Jülicher het, soos reeds vermeld, juis op grond van sy basiese onderskeid tussen vergelyking en metafoor hierdie ander onderskeidinge getref. Waar die onderskeidende komponent van die allegorie volgens hom die metafoor is, daar is dit van die vergelyking (in enger sin), parabel en voorbeeldvertelling die vergelyking (in breë sin). Die kenmerke van onderskeidelik die vergelyking (in breë sin) en die metafoor, soos dit hierbo bespreek is, is respektiewelik op die verskillende tipe gelykenisse van toepassing. Ons gaan vervolgens hierdie tipes en hulle onderskeie kenmerke baie kortliks bespreek.

\subsection{Vergelyking, parabel, voorbeeldvertelling en allegorie}

'n Vergelyking in die breë sin van die woord, soos dit hierbo aangedui is, kan uitgebreid ' $n$ narratiewe diskoers (= 'gelykenis') vorm. ' $n$ 'Gelykenis' as 'n uitgebreide vergelyking is ' $n$ vertelling waarin ' $n$ idee met behulp van ' $n$ beeld in ' $n$ verhaalvorm vertel word. Wat die gelykenisse in die Nuwe Testament betref, is dié idee uiteraard godsdienstig van aard en handel dit dikwels oor iets in verband met die koninkryk van God. Daar is dus in ' $n$ 'gelykenis' ' $n$ beeld en 'n saak aanwesig en ook 'n vergelykingspunt daartussen. Die literêre kategorieë beeldhelfte, saakhelfte en 'tertium comparationis' word derhalwe in 'n 'gelykenis' onderskei. Dit moet egter nie só opgeneem word dat die strukturele opbou van 'n 'gelykenis' formeel in hierdie drie inkomplete dele sou uiteenval nie (vgl Linnemann 1977: 24). Daar word met die term tertium comparationis verwys na die één gemeenskaplike idee wat tussen die beeld en die (godsdienstige) saak bestaan, byvoorbeeld die idee 'vreugde' in die 'gelykenis' van die afgedwaalde skaap in Lukas 15: 4-7 (vgl Steyn \& Vorster 1980). Die ander materiaal en motiewe in die 'gelykenis' funksioneer ter toeligting van die tertium comparationis.

Wat die klassifisering van sulke vertellinge in die Nuwe Testament 
betref, word daar, op grond van die genoemde basiese onderskeid tussen vergelyking (in breë sin) en metafoor, in die eerste plek tussen gelykenis aan die een kant en allegorie aan die ander kant onderskei. Soos ons hierbo daarop gewys het, is die vergelyking volgens hierdie opvatting die onderskeidende komponent van die 'gelykenis'. Die metafoor is die onderskeidende komponent van die allegorie. Omdat die materiaal van die 'gelykenis' en die enkel-elemente daarin rondom één tertium comparationis saamgegroepeer is, verwys dié elemente op 'n ondergeordende wyse met betrekking tot die één tertium comparationis deur middel van die beeldhelfte na die werklike wêreld. In 'n allegorie verwys meer as een van die enkel-elemente daarin op 'n primêre wyse, dit wil sê sonder dat daar slegs één tertium comparationis ter sprake is, na die werklike wêreld. In die sogenaamde allegorie van die huweliksmaaltyd wat die koning vir sy seun voorberei het (Matt 22: 1-14), byvoorbeeld, verwys die enkel-elemente 'seun' na Jesus Christus, die 'genooides' na die Jode, hulle 'stad' wat verbrand word na Jerusalem, die 'slawe' wat gestuur word na die dissipelsending, die 'ongenooides buite die stad' na die heidene, ensovoorts. Hierteenoor verwys, byvoorbeeld, die enkel-elemente 'veld', 'vriende en bure', ensovoorts in die 'gelykenis' van die afgedwaalde skaap (= beeld) op 'n ondergeordende wyse met betrekking tot die één idee 'vreugde', as die tertium comparationis, na die werklike wêreld. Hierdie enkel-elemente kan selfs irreëel (Engels: unusual features) (kyk Linnemann 1977: 18) wees, omdat 'n 'gelykenis' se tertium comparationis in sekere gevalle (die sogenaamde parabel = parable-proper) nie van 'n konkrete voorval in die reële wêreld uitgaan nie, maar van 'n algemene, erkende lewensfeit of ervaring (die sogenaamde vergelyking in enger $\sin =$ similitude). In ander gevalle gaan die tertium comparationis wel van 'n konkrete geval in die reële wêreld uit en vind sy toespitsing op 'n karakter as voorbeeldgeval (die sogenaamde voorbeeldvertelling = example-story). Hier vind ons die rede waarom daar in die tweede plek in 'gelykenisse' onderling ' $n$ onderskeid tussen vergelyking (in enger sin), parabel en voorbeeldvertelling getref word.

Waar die vergelyking/simiitude 'n tipiese situasie in die werklıke wereld in die oog het, daar is dit by die parabel/parable-proper 'n interessante, spesifieke geval in die werklike wêreld. Die vergelykingisimilitude word daarom dikwels ingelei met die vraag tís ex humōn Voorbeelde van vergelykings is: die suurdeeg in meel ingewerk (Matt 13: 33), die saai van ' $n$ mosterdsaad (Matt 13: 31), die saai van saad op die land (Mark 4: 26-29) en die optrede van ' $n$ baas teenoor sy slaaf 
(Luk 17: 7-10). 'n Parabel/parable-proper het as 'n vry gekomponeerde vertelling (kyk Linnemann 1977: 4) betrekking op wat enigeen kan doen, maar wat iemand eens gedoen het. Dit maak nie saak of ' $n$ ander man dit op dieselfde wyse sal doen of nie. Voorbeelde van parabels is: die oneerlike bestuurder (Luk 16:1-13), die man met die twee seuns (Matt 21: 28-32), die man wat die groot ete gegee het (Luk 14: 16-24) en die regter in 'n sekere stad (Luk 18: 2-8). Wat referensie betref, is die vergelyking/similitude dus universeel geldig, terwyl die parabel/parable-proper verwys na wat net een maal gebeur het. Kommunikatief verskaf sowel die vergelyking as die parabel nuwe informasie oor 'n saak deur middel van ' $n$ beeld aan die hoorder/leser. Eersgenoemde wil teëstand van die hoorder/leser met betrekking tot die vertelde saak vermy deur die beeld op universele geldigheid te grond. Laasgenoemde hoop om teëstand te vermy deur juis die beeld nie op universele geldigheid te bou nie, maar dit literêr so aanloklik moontlik aan te bied. Dit bring mee dat die parabel meer subtiel en daarom minder triviaal, maar meer esteties van aard as die vergelyking is. Die parabel word dikwels ingelei met die partikels hōs en hōsper of die uitdrukkinge homoios estin, homoia estin, homoiōthēsetai en homoiōthe.

Die voorbeeldvertelling (Duits: Beispielerzählung oftewel Illustration), is net soos die parabel ' $n$ free invented story en is aan dieselfde reëls van storie vertel onderworpe. Die kommunikasie-strategie is egter anders: Waar die parabel ' $n$ analogie tussen die beeld en die saak deur middel van 'n tertium comparationis skep, daar skep die voorbeeldvertelling 'n exemplum. Waar die parabel die krag van sy oorreding op die veronderstelde feit bou dat wat in die spesifieke geval in die werklike wêreld gebeur het, nie deur 'n korrelerende geval betwis kan word nie, daar word die 'ideologiese' perspektief van die verteller in die voorbeeldvertelling, op grond van die getuienis oor die spesifieke exemplum in die veronderstelde werklikheid, as gesagvol aangebied. Voorbeelde van voorbeeldvertellinge is: die ryk dwaas (Luk 12: 16-21), die ryk man en Lasarus (Luk 16: 19-31) en die Fariseër en die tollenaar (Luk 18: 9-14). Wat die vertelling oor die barmhartige Samaritaan (Luk 10: $30-37$ ) betref, is dit nie 'n uitgemaakte saak of dit as 'n voorbeeldvertelling (soos by Linnemann 1977: 4) of as 'n parabel (soos by Crossan 1973: 65) geïnterpreteer moet word nie. Pelser (1985: 471) meen dat dit geisoleerd ' $n$ betekenisvolle eenheid vorm en dat dit daarom nie meer as ' $n$ voorbeeldvertelling beskou kan word nie, maar as 'n parabel.

Wat die allegorie betref, is dit net soos die parabel, ' $n$ koherente, vry gekomponeerde vertelling wat oorreding as bedoeling het. Die funksie 
van die allegorie is dat dit 'n evaluering van die werklike wêreld bied sonder dat dit nuwe informasie daaroor verskaf, sodat dié evaluasie deur die hoorders/lesers gedeel kan word. Die allegorie is daarom op die werklike wêreld gemodelleer. Die saak waarom dit in die allegorie gaan, word in terme van 'n reeks beelde (= referensie-items) wat op die werklike wêreld betrekking het, gegee. Tog bly die werklikheid bedek, sodat net die ingewydes die allegorie kan interpreteer. Dit sê met ander woorde iets anders as wat bedoel word. Waar die parabel by voorkeur tot opponente gerig is, daar rig die allegorie hom dus tot ingeligtes. Volgens Linnemann (1977: 8) is die vertelling oor die huwelikmaaltyd in Matteus 22: 1-14 die enigste onbetwisbare allegorie waarvan Jesus gebruik gemaak het. Sy meen dat dié oor die tien meisies (Matt 25: 1-13) en die boere en die wingerd (Mark 12:1-12) nie allegorieë is nie. Die toepassing wat in die mond van Jesus op onderskeidelik die parabel oor die saaier (Mark 4: 3-9; Matt 13: 1-9; Luk 8: 4-8) gemaak is, naamlik Markus 4: 13-20, Matteus 13: 18-23 en Lukas 8: 11-15, is wel allegories van aard, maar die vertelling self is nie ' $n$ allegorie nie. Dit geld ook die toepassing op die parabel oor die treknet (Matt 13: 47-48), naamlik Matteus 13: 49-50.

\section{KRITIEK OP DIE TRADISIONELE KLASSIFIKASIE}

Uit wat sover in die bespreking vorendag gekom het, is dat veral twee aspekte in gelykenisnavorsing die fondament van die tradisionele klassifikasie blyk te wees. Dit is naamlik referensie en metaforisiteit. Een ding staan ook vas en dit is dat Jesus se gelykenisse verteltekste is. Wanneer narratiwiteit egter ernstig in gelykenisinterpretasie opgeneem word, begin bogenoemde fondament krake vertoon (kyk Van Aarde [1985]). Die rede hiervoor is dat daar in die narratologie met nuwe insigte na die referensie van verteltekste gekyk word. Hierdie nuwe insigte, sowel as ' $n$ veranderde opvatting oor metaforisiteit wat veral in nuwe-hermeneutiese kringe voorkom, maak dat die formgeschichtliche kategorieë hulle pragmatiek met die oog op die prediking verloor.

Die tradisionele klassifikasie van Jesus se gelykenisse kan myns insiens gehandhaaf word, mits dit uit hulle onderskeie holistiese ko(n)tekste geìsoleer word. Maar dan moet die implikasies - historiese, literêre en teologiese - van so ' $n$ isolering deeglik in ag geneem word. Vorster (1985c: 157) verwys soos volg hierna: 
'... dit (is) duidelik dat die bestudering van die gelykenisse van Jesus in isolasie bepaalde konsekwensies het. Indien hulle as estetiese objekte beskou word, word daar betekenisse aan hulle toegeken wat anders is as wanneer die gelykenisse binne die konteks waarin hulle oorgelewer is, of na aanleiding van die rede waarom hulle vertel is, geanaliseer word. Kontekslose vertellings het ook ander funksies as vertellings wat om ' $n$ rede wat deur die onnatuurlike konteks bepaal word, vertel word. ' $n$ Mens kan met gelykenisse soos met ander taaluitinge verskillende dinge maak. Daarom is dit van belang dat hierdie sake aandag kry in die bestudering van die gelykenisse van Jesus.'

'n Isolering van Jesus se gelykenisse bemoeilik die volledige implementering van narratiwiteit in die interpretasie daarvan. Hierbenewens moet ' $n$ funksionele aanwending van die tradisionele klassifika. sie die ou metafooropvatting bly handhaaf. Party Nuwetestamentici meen dat ' $n$ kompromis miskien moontlik is, soos byvoorbeeld Snodgrass (1983: 24):

'Whether one defines allegory as extended metaphor or a series of metaphors, the question "Can a parable be an allegory?" must be answered affirmatively ... This is not a license for fanciful exegesis since such significance, must be rooted in the historical and literary context.'

Aan die ander kant sê hy: 'Whether one chooses to call this story (dié oor die boere en die wingerd - AG v A) a "parable", an "allegory", or both is not really important' (Snodgrass 1983: 25). Waarom dan die genre-jargon? Waarom word daar nie bloot van 'n metaforiese vertelling gepraat nie?

\subsection{Metaforisiteit, narratiwiteit en referensie}

Jülicher se onderskeid tussen vergelyking (in breë sin) en metafoor word lankal nie deur bekende gelykenisnavorsers sonder meer (o a Via 1967; Crossan 1976) of glad nie meer (o a Klauck 1978; Weder 1978; Sellin 1982) aanvaar nie. Metaforisiteit word vandag nie meer as blote ornamentele diksie opgeneem nie. Inteendeel, 'n verteller skep met behulp van ' $n$ metafoor ' $n$ nuwe werklikheid wat uit die oogpunt van affektiewe lesersbetrokkenheid beleef en gedeel kan word (vgl Weder 1978: 75). 
Die klassieke onderskeid vind volgens Klauck (1978) sy oorsprong in Jülicher se wegbeweeg vanaf allegorese. Dit was op sigself 'n verreikende bydrae. Hy het egter allegorese as eksegetese tegniek en allegorie as literêre vorm met mekaar verwar. Die kenmerke van allegorese is (vgl Klauck 1978: 354-361): (1) ongeinteresseerdheid in die literêr-estetiese en historiese aspekte van ' $n$ teks, (2) anachronistiese 'eisegese' vanuit ' $n$ vooronderstelde perspektief, (3) ' $n$ veronderstelling dat ' $n$ teks ' $n$ esoteriese kommunikasie-kode bevat wat die bedoeling daarvan bedek en daarom slegs aan ingeligtes gerig is, en (4) ' $n$ interpretasieproses waarin tekste en enkel-elemente geïsoleer en in 'n nuwe konteks ingeruk word.

Dan Via (1967: 24-25), weer, handhaaf wel die onderskeid tussen 'n parabel en 'n allegorie, maar verwerp Jülicher se opvatting dat eersgenoemde slegs een direkte vergelykingspunt (tertium comparationis) met betrekking tot die werklike wêreld sou hê en laasgenoemde meer (kyk later). Hierdie siening is gedeeltelik op Ernst Fuchs se nuwe-hermeneutiek gebou. Hoewel Fuchs (1958: 213-214; 217-219) die onderskeid tussen ' $n$ vergelyking en ' $n$ metafoor handhaaf, meen hy dat die prinsiep 'analogie' die belangrikste kenmerk van 'n metafoor is. Fuchs is hierin deur Eta Linnemann nagevolg.

Linnemann toon aan dat die verteller deur middel van die prinsiep 'analogie' sý evaluasie van die werklikheid aan die hoorder/leser wil oordra. Sodoende word die moontlikheid van 'n nuwe verstaan van die werklikheid vir die hoorder/leser geskep. Die feit dat die verteller die hoorder/leser tot oorreding (Einverständnis) wil bring, maak dat hy iets aan die hoorder/leser moet toegee. Die toegewing is die prinsiep 'analogie'. Dit wat vir die hoorder/leser onbekend is, naamlik die verteller se evaluasie van die werklikheid, word deur middel van die metaforiese vertelling in terme van die bekende gestel. Hoe meer ongewoon die verteller se evaluasie is, hoe versigtiger en subtieler moet die toegewing gedoen word. Die krag van die oorreding is met ander woorde afhanklik van die verteller se sukses om die 'wêreld' van die hoorder/leser só met die 'wêreld' van die vertelling literêr te integreer, dat die 'analogie' wat sodoende tussen die verteller en die hoorder/leser geskep is, laasgenoemde in die vertelling intrek sonder dat eersgenoemde sy manipulerende posisie as verteller te opsigtelik maak en daarom hierdie posisie verloor (vgl Linnemann 1977: 28).

Robert Funk (1966) het die nuwe-hermeneutici se beklemtoning van die 'Sprachkraft der Existenz' (Fuchs), uitgedruk in metaforiese taal, nog verder gevoer. Hy het daarom verkies om eerder van ' $n$ 'parabel as 
metafoor' in plaas van ' $n$ 'parabel as analogie' te praat. Tog is narritiwiteit as sodanig nog nie in gelykenisinterpretasie geëksploiteer nie. GV Jones (1964) het dit geïnisieer, maar dit was eintlik eers Dan Via wat die gelykenisse van Jesus op 'n eksistensiale wyse as 'genuine works of art' begin interpreteer het. Volgens Via (1967: 178-179) bied die gelykenisse egter weerstand om as mikro-tekste in die lig van die holistiese ko(n)teks van 'n evangelie as vertelling geïnterpreteer te word (vgl Pelser 1985: 464). So 'n standpunt maak dat Jesus se gelykenisse as bloot 'free-floating' mikro-tekste figureer (vgl Kingsbury 1972: 107). Dit bemoeilik derhalwe dat die narratiwiteit van 'n gelykenis tot sy volle reg in die interpretasie daarvan kom (vgl Van Aarde [1985]).

In die inleiding van die onderhawige artikel is betoog dat dit veral die genre van ' $n$ teks is wat die pragmatiek daarvan help bepaal. Die literêre genre is die 'holistiese ko(n)teks' (vgl Talbert 1977: 11) van geskrewe taalgebruik en dien as die sleutel vir die verstaan van die onderdele. Dit geld vir woorde in ' $n$ sin en sinne in ' $n$ perikoop en perikope in die teks as geheel (vgl Güttgemanns 1979: 290). Die 'teks as geheel' is wat deur Talbert die 'holistiese ko(n)teks' genoem word en waarmee 'literêre genre' bedoel word. Petersen (1970) en Hirsch (1967), onderskeidelik, formuleer die hermeneutiese relevansie van genre-ondersoek soos volg:

'In all cases, genre has to do with the intended meaning of a total text as composed, and therefore with the traits by which this meaning is to be recognised' (Petersen 1970: 82 noot 7).

'All understanding of verbal meaning is necessarily genre-bound. This description of the genre-bound character of understanding is, of course, a version of the hermeneutic circle, which in its classical formulation has been described as the interdependence of part and whole: the whole can be understood only through its parts, but the parts can be understood only through the whole' (Hirsch 1967: 76).

Wat is die implikasie van ' $n$ inagneming van die holistiese ko(n)teks van 'n evangelie as vertelling vir die tradisionele klassifikasie van Jesus se gelykenisse? Aan die een kant moet die sogenaamde allegoriserende toepassings op sekere 'parabels' waarna ons vroeër verwys het, as vertellerskommentaar beskou word. Aan die ander kant moet die sogenaamde 'parabels' self as direkte redes wat as besprochene Welt die erzählte Welt onderbreek, geïnterpreteer word (vgl Vorster [1985a]). Die direkte rede (besprochene Welt) het meer 'n evaluerende as ' $n$ informa- 
tiewe funksie. Vorster pas hierdie narratologiese insig soos volg op respektiewelik die Markusevangelie as geheel en die parabeldiskoers in Markus 4: 1-34 toe:

'In terms of the structure of Mark's narrative in which narrative discourse and direct discourse is continually alternated and where the sayings of Jesus, as we have seen often serve the function of presenting norms for the reader, this is not without significance. It gives an indication of how the author wished his readers/hearers to interpret the ... story' (Vorster [1985a]).

'In Mark 4: 1-34, the focus is like elsewhere in the gospel when Jesus speaks ... on ... what he says and why he says it. The function of the speech is first of all, as with all the other sayings of Jesus in Mark, to create a context of evaluation for the reader. Besides the information it offers ..., it also provides the reader with norms to evaluate the actions of other characters in the story' (Vorster [1985a]).

Myns insiens is die belangrikste kenmerk van 'n metaforiese vertelling dat dit 'n polivalente strekking het. Dit kom daarop neer dat só 'n vertelling ten minste op twee betekenisvlakke geïnterpreteer kan word, naamlik die letterlike en die figuurlike. Die kommunikatiewe gerigtheid van ' $n$ metaforiese vertelling geskied perspektivisties vanuit die betekenisverband tussen die 'letterlike' en die 'figuurlike'. Hierdie kenmerk geld alle (tipe) gelykenisse in die evangelies. Die voorwaarde is dat dit as mikro-tekste binne hulle onderskeie holistiese ko(n)tekste geïnterpreteer moet word. Vanuit 'n pragmatiese doelwit, soos die prediking, het die tradisionele klassifikasie van Jesus se gelykenisse dus sy funksie verloor. As die metaforiese vertellinge in die evangelies wel getipeer moet word, kan dit raaisels (vgl Rhoads \& Michie 1982: 55-58) genoem word. As 'raaisels' moet dit op grond van die riglyne wat die verteller bied, sover as wat dit moontlik is, ontknoop word.

Deur narratiwiteit in gelykenisinterpretasie ernstig op te neem, kan twee ander probleme wat met die klassieke klassifikasie verband hou, opgelos word. Die een is dat daar in 'n vergelyking (in breë sin), en in die ondergeordende, verwante tipe gelykenisse, slegs van één tertium comparationis sprake kan wees en nie van meer nie (bv Linnemann). Die ander is dat 'n vergelyking (en verwante tipes) na aanleiding van sy tertium comparationis verklaar moet word (bv Via).

Wat die eerste vraagstelling betref, kan Linnemann (1977: 24-25) se 
standpunt dat daar meer as één Beziehungspunkt kan figureer, gelyk gegee word. Hoe meer kompleks 'n metaforiese vertelling is, hoe meervlakkig manifesteer die 'ideologiese' perspektief van die verteller en hoe minder is daar sprake van 'n eenduidige 'betekenisverband' tussen die letterlike en die figuurlike. Hierdie soort kompleksiteit is egter in triviale, folkloristiese tipe literatuur, soos Jesus se gelykenisse, beperk. Estetiese literariteit is hier eerder die buitengewone.

Wat die tweede vraagstelling betref, bestaan Via (1967: 70-72) se probleem daaruit dat die tertium comparationis 'n referensiële punt met betrekking tot iets buite die gelykenis self is. Hy kan nie vanuit 'n struktureel-eksegetiese benadering hiermee genoeë neem nie. Omdat die struktuur van 'n gelykenis sentripetaal na binne georganiseer is, is dit volgens hom allegoriserende eksegese om 'n gelykenis na aanleiding van sy buite-tekstueel-refererende tertium comparationis te verklaar. Hier lê klaarblyklik die rede waarom hy enersyds die onderskeid tussen 'parabel' en 'allegorie' handhaaf en andersyds die gelykenisse van Jesus as geïsoleerde estetiese objekte hanteer. Via se probleem is op die keper beskou, 'n kwessie rakende die wyse waarop verteltekste intern en ekstern refereer.

Vorster [1985b] se bydrae in hierdie verband, dit wil sê met betrekking tot referensie, is myns insiens van belang. Hy wys daarop dat die referensie-items in 'n vertelling op twee maniere verwys, naamlik 'eksofories' en 'endofories' (Halliday en Hason se terminologie). Eersgenoemde het te doen met die referensie met betrekking tot die wêreld buite die mikro-teks sowel as buite die makro-teks. Hierdie 'wêreld' is die situasionele konteks. Laasgenoemde tipe verwysing het te doen met die referensie met betrekking tot die so genoemde ko-teks. Hierdie 'wêreld' is die holistiese ko(n)teks waarin die mikro-teks voorkom.

Beide tipe verwysings is, wat die gelykenisse in die evangelies betref, ekstern van aard. Die een is 'histories' en die ander literêr. Die konsepte Anschaulichkeit en Substitution is by geeneen ter sake nie. En hiermee val die bodem van die tradisionele klassifisering van Jesus se gelykenisse uit. Prinsipieel is daar geen verskil in enigeen van die metaforiese vertellinge binne die evangelies met betrekking tot ò die analogie-prinsiep òf die referensie-wyse nie.

\section{DIE METAFORIESE VERTELLING OOR DIE BARMHARTIGE SAMARITAAN IN DIE LUKASEVANGELIE}

Wat is die implikasies van die voorafgaande betoog oor metaforisiteit 
en referensie vir die interpretasie van die vertelling oor die barmhartige Samaritaan (Luk 10: 25-37) met die oog op die prediking?

Bo alles behoort die kwessie of die vertelling ' $n$ 'parabel' of ' $n$ 'voorbeeldvertelling' sou wees, buite diskussie te staan. Indien dit ' $n$ 'voorbeeldvertelling' sou wees, sal die krag van die verteller se oorreding in sy karakterisering van die barmhartige Samaritaan as exemplum geleë wees. Indien dit ' $n$ 'parabel' sou wees, sal die krag van die oorreding gebou wees op die veronderstelling dat wat vertel word, nie deur 'n korrelerende geval betwis kan word nie. Dit is te betwyfel of die inagneming van hierdie verskil kan help om die eintlike kommunikatiewe intensie van die betrokke gelykenis bruikbaar vir die prediking te mak. Indien dit wel moontlik sou wees, moet iemand dit uitspel.

Wanneer daar egter met die beginsel 'metaforisiteit' in narratologiese verband erns gemaak word, hou die interpreteerder met die polivalente gerigtheid en die dubbele referensie van die vertelling rekening. Die dominante idee in die vertelling, en nie net 'n bepaalde karakter as exemplum nie, verwys 'endofories' met betrekking tot die Lukaanse koteks en 'eksofories' met betrekking tot die 'historiese', situasionele konteks van die beoogde leser(s). Deur die polivalensie en die dubbele referensie met mekaar in verband te bring, kry die referensie-items in die vertelling ' $n$ transparante strekking. Die bedoeling van die stelling word in die lig van die funksionele plek van die betrokke metaforiese vertelling binne die Lukaanse ko-teks duidelik.

Die Lukasevangelie en die Handelinge van die apostels is twee geskrifte wat die werk van dieselfde skrywer is. Dit is duidelik dat hierdie twee boeke deur die skrywer as 'n eenheid gesien is. Die Lukasevangelie-Handelinge-korpus vorm dus die holistiese ko-teks waarbinne die gelykenis van die barmhartige Samaritaan funksioneel 'n plek het. In altwee geskrifte is die kern van die onderskeie boodskappe dieselfde, naamlik dat God in Jesus Christus verlossing vir die mensdom aanbied. In die Lukasevangelie word God se heil vir Israel aangebied en in die Handelinge van die apostels bied die kerk as die 'ware Israel' dit in die Naam van Jesus vir die wêreld buite die Jodedom aan. Vooruitflitse en terugflitse vanuit die een na die ander kom dikwels voor. Hierdie boodskap het dus die vorm van wat genoem kan word die geskiedenis van God se heil (vgl o a Rengstorf 1969: 6 en Danker 1976: 2): eers word dit vir Israel aangebied en dan deur die kerk, bestaande uit Jode en nie-Jode, vir 'n hele wêreld. Jesus Christus self is die middelpunt van dié heilsgeskiedenis (vgl Conzelmann 1977): die geskiedenis van God se heil vind sy hoogtepunt in sy lewe, sterwe 
en opstanding en vanuit hierdie gebeure vul dit vanaf pinkster die lewe van die kerk op sy weg van sending in die wêreld.

Dié Lukaanse boodskap is in die vorm van twee, maar aaneengeskakelde, reisvertellinge gegiet. In die Lukasevangelie word baie episodes wat oor Jesus se werk en optrede handel en volgens die Markus- en Matteusevangelies op Galileese bodem plaasgevind het, plek gegee op Jesus se reis vanaf Galilea na Jerusalem en die tempel as die sentrum van Israel. Die grootste deel van die Lukasevangelie het in der waarheid hierdie reis as inhoud, naamlik Lukas 9: 51-19:27/44. Die dissipels wat in die Lukasevangelie, anders as in die ander twee Sinoptiese Evangelies, nie as 'n groep apart van Israel geteken word nie (vgl Kingsbury 1981: 122-123), word tydens hierdie reis opgeroep om onmiddellik en onvoorwaardelik Jesus te volg (kyk Luk 9: 57-62). Diegene wat dit doen, gee te kenne dat hulle hulle assosieer met dit wat hierdie reis na Jerusalem impliseer. Diegene wat dit nie doen nie, sluit hulleself uit die kring van die 'ware Israel' uit (kyk Luk 22:30) en is derhalwe nie geskik vir die reis na Jerusalem (kyk Luk 9:60, 62 - vanuit 'n agterna-perspektief) en vandaar (kyk Luk 24: 52-53 - vanuit 'n vooraf-perspektief) na Rome nie. Soos die Lukasevangelie op Jerusalem afstuur, stuur die Handelinge van die apostels op Rome af. Rome, as die destydse hoofstad van die wêreld, is in die lig van die Lukaanse koteks die simboliese eindpunt van die verhaal oor die geskiedenis van God se heil (kyk Hand 28: 30-31).

Die gelykenis van die barmhartige Samaritaan (Luk 10:30-37) is die eerste metaforiese vertelling wat in die genoemde vertelling oor die reis van Jesus vanaf Galilea na Jerusalem voorkom, naamlik Lukas 9: $51-19: 27 / 44$. In dié reisvertelling word twee teenoorstaande 'ideologiese' perspektiewe belig: dié van die Jode se godsdienstige leiers en dié van Jesus self (vgl Resseguie 1982). Jesus se direkte redes, waarvan die meeste metaforiese vertellinge is, funksioneer as besprochene Welt wat die erzählte Welt onderbreek. Hierdie 'bespreekte' diskoerse verskaf inligting van die verteller se 'ideologiese' perspektief wat gedra word deur dié van Jesus. Dit is die perspektief van waaruit die leser die 'ideologiese' perspektiewe van die ander karakters, soos dié van die Joodse leiers, her-evalueer. Laasgenoemde s'n kan bestempel word as 'n formalistiese godsdiens sonder 'n hart vanweë 'n hubris-georiënteerde visie.

Die sentrale reisvertelling word ingelei met 'n kort vertelling oor die inwoners van 'n Samaritaanse dorp wat weier om Jesus, op pad na Jerusalem toe, herberg te gee. Die dissipels wil hê dat die Samaritane 
met vuur verteer word, maar Jesus bestraf hulle (Luk 9: 51-56). Nadat die dissipels moes hoor wat egte navolgingskap inhou (Luk 9: 57-62), word hulle op hulle suksesvolle wêreld-sending, een van die vooruitflitse in die Lukaanse ko-teks, gestuur (Luk 10: 1-24). Daarna volg die gelykenis van die barmhartige Samaritaan.

Dié metaforiese vertelling word binne die raamwerk van die genoemde botsende 'ideologiese' perspektiewe van onderskeidelik Jesus en die Jode gekontekstualiseer (Luk 10: 25-29). Die kernvraag van die dispuut is hier: 'Wie is my naaste?' (Luk 10:29). Die opponent word op so ' $n$ wyse deur middel van die analogie-prinsiep in die metaforiese vertelling ingetrek dat hy self die antwoord op die vraag gee: Dit is nie die priester of die Leviet wat die naaste aan die verontregte is nie, maar die Samaritaan! (Luk 10: 36-37).

Die volgelinge van Jesus verneem in bogenoemde vertelling weer eens wat die pad na Jerusalem inhou, naamlik ' $n$ keuse teen ... en vir .... Dit vereis 'n eksistensiale aanname van 'n visie wat onmoontlik lyk. Dit is naamlik 'n keuse vir die Jesus-saak wat enersyds deur die Samaritane geweier word en andersyds deur 'n Samaritaan beliggaam is. 'Endofories' verwys die vertelling na die spanning-beleefde lewe van die dissipels op pad Jerusalem toe en dié van die kerk op pad Rome toe. 'Eksofories' verwys dit na die spanning wat die uitbly van Jesus se wederkoms vir die vroeë kerk ingehou het (vgl veral Luk 9: 27; 12: 38-40; 16:16 en Conzelmann se ekklesiologiese term ecclesia pressa), en ook vir ons vandag.

So gesien, kan die prediking van die gelykenis van die barmhartige Samaritaan die kerk steeds tot ' $n$ 'nuwe-verstaan' met betrekking tot sy taak in die wêreld bring.

\section{Literatuurverwysings}

BULTMANN, R 1967. Die Geschichte der synoptischen Tradition. 7. Aufl. Göttingen: Vandenhoeck \& Ruprecht.

CONZELMANN, H 1977. Die Mitte der Zeit: Studien zur Theologie des Lukas. 6. Aufl. Tübingen: Mohr.

CROSSAN, JD 1973. In parables: The challenge of the historical Jesus. New York: Harper \& Row.

CROSSAN, JD 1976. Parable, allegory and paradox, in Patte, D (ed), Semiology and the parables, 264-271. Pittsburgh: Pickwick.

DANKER, FW 1976. Luke. Philadelphia: Fortress. (Proclamation commentaries.)

DIBELIUS, M 1971. The Formgeschichte des Evangeliums. (Hrsg von G Bornkamm). 6. Aufl. Tübingen: Mohr.

DOTY, WG 1972. The concept of genre in literary analysis, in McGoughy, LC (ed), SBL Proceedings. Vol. 2. Book of seminar papers, 413-448. Philadelphia: Fortress.

FUCHS, E 1958. Hermeneutik. 2. Aufl. Bad Cannstatt: Müllerschön.

FUNK, R 1966. Language, hermeneutic, and word of God. New York: Harper \& Row. 
GÜTTGEMANNS, E 1979. Candid questions concerning gospel from criticism: A methodological sketch of the fundamental problematics of form and redaction criticism. (Translated by WG Doty). Pittsburgh: Pickwick.

HIRSCH, ED 1967. Validity in interpretation. New Haven: Yale University Press.

JONES, GV 1964. The art and truth of the parables. London: SPCK.

JÜLICHER, A 1910. Die Gleichnisreden Jesu. 2. Aufl. Tübingen: Mohr. KINGSBURY, JD 1972. The parables of Jesus in current research. Dialog 11, 101-107.

KINGSBURY, JD 1972. The parables of Jesus in current research. Dialog 11, 101-107. (Proclamation commentaries.)

KISSINGER, WS 1979. The parables of Jesus: $A$ history of interpretation and bibliography. Metuchen: Scarecrow.

KLAUCK, H-J 1978. Allegorie und Allegorese in synoptischen Gleichnistexten. Münster: Aschendorff.

LATEGAN, BC \& VORSTER, WS [1985]. Text and reality: Aspects of reference in biblical texts. Missoula: Scholars. (Forthcoming.)

LINNEMANN, E 1977. Parables of Jesus: Introduction and exposition. (Translated by J Sturdy). London: SPCK.

PELSER, GMM 1985. Die verhouding tradisie-redaksie in gelykenisinterpretasie. HTS 41.

PETERSEN, NR 1970. So-called gnostic type gospels and the question of the genre "gospel", in SBL for task group on gospel genre. Unpublished seminar papers.

RENGSTORF, KH 1969. Das Evangelium nach Lukas. Göttingen: Vandenhoeck \& Ruprecht. (NTD.)

RESSEGUIE, JL 1982. Point of view in the central section of Luke (9: 51-19:44). JETS 25, 41-47.

RHOADS, D \& MICHIE, D 1982. Mark as story: An introduction to the narrative of a gospel. Philadelphia: Fortress.

SELLIN, G 1982. Allegorie und "Gleichnis": Zur Formenlehre der synoptischen Gleichnisse, in Harnisch, W (Hrsg), Die neutestamentliche Gleichnisforschung im Horizont von Hermeneutik und Literaturwissenschaft, 367-429. Darmstadt: Wissenschaftliche Buchgesellschaft. (Wege der Forschung 575.)

SNODGRASS, K 1983. The parable of the wicked tenants: An inquiry into parable interpretation. Tübingen: Mohr. (Wissenschaftliche Untersuchungen zum Neuen Testament 27).

STEYN, J \& VORSTER, WS 1980. Die kanon van die Nuwe Testament en die eksegese van die Sinoptiese Evangelies. Pretoria: UNISA. (Studiegids Nuwe Testament BDI NTE 501.)

TALBERT, CH 1977. What is a gospel? The genre of the canonical gospels. Philadelphia: Fortress.

VAN AARDE, AG 1982. God met ons: Dié teologiese perspektief van die Matteusevangelie. DD-proefskrif, Universiteit van Pretoria.

VAN AARDE, AG [1985]. Plot as mediated through point of view: Matthew 22: 1-14-A case study, in Petzer, JH (ed), Metzger Festschrift. Grand Rapids: Eerdmans. (Forthcoming.)

VIA, DO 1967. The parables: Their literary and existential dimension. Philadelphia: Fortress.

VORSTER, WS [1985a]. Meaning and reference: The parables of Jesus in Mark 4, in Lategan, BC \& Vorster, WS [1985].

VORSTER, WS [1985b]. Reader-response, redescription and reference: 'You are that man' (2 Sm 12:7), in Lategan, BC \& Vorster, WS 1985.

VORSTER, WS 1985c. Gelykenisse in konteks: Matteus 13 en die gelykenisse van Jesus. HTS 41, 148-165.

WEDER, H 1978. Die Gleichnisse Jesu als Metaphern: Traditions- und redaktionsgeschichtliche Analysen und Interpretation. Götingen: Vandenhoeck \& Ruprecht.

WREGE, H-T 1978. Dic Gestalt des Evangeliums: Aufbau und Struktur der Synoptiker sowie der Apostelgeschichte. Frankfurt am Main: Peter Lang. 